\title{
Notary Role in Issuing Bonding Guarantee of Bilyets Deposits as Collateral Credit on Loan Agreement Process (Case Study in Kanca BRI Blora)
}

\begin{abstract}
Yongky Pratama ${ }^{1}$, Nanang Suhendar ${ }^{2}$ and Achmad Sulchan ${ }^{3}$
Abstract. The purpose of this study was to: 1) Determine the implementation of binding guarantee term deposit certificate as collateral credit on the loan agreement. 2) The role of the notary in binding guarantee term deposit certificate as collateral on the loan agreement. 3) Analyze the challenges and solutions for binding guarantee term deposit certificate as collateral credit on the loan agreement (case study in Kanca BRI Blora). The method is a juridical sociological approach to the specification of descriptive analytical research. Sources of data obtained through interviews and literature.

Based on the research results implementation binding guarantee slip deposits as collateral on the loan agreement in BRI Blora starting from the stage of the loan application, the stage of the agreement and the making of the loan agreement, the stage of a deed binding guarantee deposit slip, the submission phase objects assurance, the stage of the authorization, and blocking stage or in the event of default. In binding guarantee term deposit certificate as collateral on the loan agreement in Kanca BRI Blora, Notary make a letter of agreement and binding guarantee deposit slips. Barriers just a lack of understanding about people who do the will of credit, so the solution the Bank must give a detailed explanation before binding treaty process.

Keywords : Collateral Credit; Guarantees Binding; Temporary Bilyet Deposits.
\end{abstract}

\section{Introduction}

Act No. 2 of 2014 concerning amendments to the Act No. 30 of 2004 concerning on Notary is the realization certainty of law, order and legal protection that core the truth and fair. Through the deed which made by notary could provide legal certainty to the user community notary services. Deed made by or before a Notary may be evidence of an authentic in providing legal protection to any interested parties to the deed of the certainty of events or legal actions were carried out. ${ }^{4}$ Notary is a public official authorized to make an authentic deed as far as the manufacture of certain authentic deed is not reserved for other public officials. Deed made before a notary public is an authentic proof of evidence is perfect, with all its consequences ${ }^{5}$. Authentic act as a Notary product bound in the provisions of civil law, especially in the law of evidence. Notary Deed does not qualify as an administrative decision which is concrete, individual and final, and the deed is the formulation of the desire or the will of the parties set forth in the notarial deed made before or by notary and not the will of the Notary ${ }^{6}$.

Increased economic activities directly impact business improvement and human needs become higher yet, they were not always followed by the financial ability of economic

\footnotetext{
${ }^{1}$ Students of Master of Notary Law, Faculty of Law, Universitas Islam Sultan Agung email yongkipratama90@gmail.com

2 Students of Master of Law, Faculty of Law, Universitas Islam Sultan Agung email nanangsuhendarpolri2018@gmail.com

${ }^{3}$ Lecturer of Faculty of Law Unissula Semarang

${ }^{4}$ See Explanation of Act No. 2 of 2014 concerning on Notary.

${ }^{5}$ A. Kohar, 1983, Notaris Dalam Praktek Hukum, Alumni, Bandung, p. 64.

${ }^{6}$ Habib Adjie, 2008, Sanksi Perdata dan Administratif Terhadap Notaris Sebagai Pejabat Publik, Refika Aditama, Bandung, p. 15.
} 
agents. One way in which economic actors to meet their financial needs is by borrowing funds or capital known as credit, either through the government or through a commercial bank private bank.

General Explanation of Act No.10 of 1998 on Banking. Act No. 7 of 1992 concerning Banking as amended by Act No. 10 of 1998 concerning Banking (hereinafter called the Banking Act) provides guidance in order to implement the lending banks always based on the belief that the debtor is able to repay the loan obtained at the agreed time. To support the lender in obtaining the certainty of return or repayment of debt, should be a guarantee as a condition of the loan application. Collateral or guarantees as one of the elements assessed, can be goods, the project, the right to collect financed by credit and when it comes to land, agrarian law specifically regulates ${ }^{7}$. The provision of collateral as a condition of the loan was intended if the debtor does not fulfill the obligation to repay the debts or the debtor deliberately did not keep the deadline a debt (default), then in this case the collateral may be sold in public and proceeds from the sale of the collateral will be used to pay off debts to the the creditors.

Kanca BRI Blora continues to develop itself in order to provide more excellent service and quality with emphasis on the principles of prudence and good governance. BRI's business focus is in the commercial sector, retail and consumer. In the office network development strategy, Kanca BRI Blora prioritizes the expansion of market share in the segment of small and medium enterprises (SMEs), as well as establishing joint financing with financial institutions such as rural banks (BPR) and finance companies. in channeling loans, Kanca BRI Blora receive a guaranteed principal and additional guarantees, for example, is a deposit which can be used as loan collateral. If the deposits can be used as loan collateral deposits must have certain procedures and institutions in terms of the binding guarantee. Binding of time deposits in each bank guarantee still seems to be different because it adapted to each bank's policy, but at Kanca BRI Blora binding guarantee deposits in doing the credit agreement. This is the background of the author to examine under the title "Notary Role In Issuing Bonding Guarantee Of Bilyets Deposits As Collateral Credit On Loan Agreement Process (Case Study In Kanca BRI Blora)".

\section{Research methods}

The method used in this research is juridical sociological. Juridical Sociological is a legal research using secondary data as the data first, followed by primary data or data field ${ }^{8}$. Specifications research is analytic descriptive describes the applicable laws and regulations associated with the law theories and practice implementation ${ }^{9}$. Primary data were collected by interview. The interview is a process of questions and answers in ongoing research orally in which two or more face-to-face hearing directly information or particulars ${ }^{10}$. Type of interview used in this study using a free guided interview, is a combination of free and guided interview ${ }^{11}$. Secondary data is data obtained from a review of the literature or the review of the literature or library materials related to the problem or research materials that are often referred to legal materials ${ }^{12}$. Analysis of the data used in this research is the analysis of qualitative data that have been obtained from field studies and literature will be collected and grouped systematically in accordance with the facts and characteristics of the

\footnotetext{
${ }^{7}$ Indrawati Soewarso, 2002, Aspek Hukum Jaminan Kredit, Institut Bankir Indonesia, Jakarta, p. 3

${ }^{8}$ Amiruddin, 2012, Pengantar Metode Penelitian Hukum, Rajagrafindo Persada, Jakarta, p.15

${ }^{9}$ Sumardi Suryabrata, 1993, Metodologi Penelitian, Rajawali, Jakarta, p.19

${ }^{10}$ Ronny Hanitijo soemitro, 1982, Metodologi Penelitian Hukum, Ghalila Indonesia,. Jakarta, p. 83

${ }^{11}$ Ibid , p. 84

12 Mukti Fajar dan Yulianto, 2010, Dualisme Penelitian Hukum Normatif dan Empiris, Pustaka Pelajar, Yogyakarta, p. 156
} 
object under study is appropriate and then analyzed qualitatively with the aim of getting a conclusion on the issue research ${ }^{13}$.

\section{Discussion}

\subsection{Application of Bonding Guarantee Of Bilyets Deposits As Collateral Credit On Loan Agreement Process In BRI Blora}

When a bank decides to give credit to its customers, it is only logical for the bank asked for collateral. Guarantee it will be the last bastion of defense of the bank. Quality assurance is precisely what determines whether a bank can reclaim the funds distributed in the future if the debtor has failed to perform its debt repayment, in accordance with Article 8 of the Banking Act of 1998.

Acceptance of deposits as loan collateral by the bank would be a matter that is very advantageous, because of the availability of the value to be gained by banks when a loan has become problematic (loss) can be said to have assured (certainty readmission of loans). By contrast, if the guarantee received by the bank or bills are shaped object that has volatile nature in terms of value (if executed). Deposits can be the object of pledge for deposits fall into the category of moving objects, by itself, also entitles that is the right material that provides direct power over an object that can be maintained against any person.

Agreement stipulated in the Civil Code in the third book of the engagement, the second chapter, part of unity until the fourth section. Meanwhile, mortgage deposits other than stipulated in the Civil Code book II of the material, should also be subject to the book III of engagement for the pawn deposit is an agreement which entitles the indebted on deposits were submitted to him as collateral by a debt or by others on their behalf and give power to the indebted to take repayment of the goods are given precedence over other indebted. In addition the deposit pledge agreement was evidenced by all the means that allowed for approval of proof staple in this case the credit agreement ${ }^{14}$.

In Blora regency, some middle class people down using the services of banking credit, in addition to interest relative decline also uncomplicated process using this banking credit agreement surrounding communities can count on a quick cash loans available if really needed. Bank as creditor or lender in lending to borrowers need to hold an agreement known as the credit agreement. The credit agreement itself must be signed or approved by the creditor and the debtor. Debtor here can as the owner of the guarantee and could also guarantee that the debtor is not the owner of a third party as owner of the guarantee. In a loan agreement required the existence of a collateral for the loan returning certainty to creditors ${ }^{15}$.

Implementation binding guarantee term deposit certificate as collateral on the loan agreement in Kanca BRI Blora conducted through several phases ${ }^{16}$ :

- The Borrower shall make application to the Bank BRI as creditor to the credit agreement, once established agreement by both parties on the terms proposed, then there was an agreement between the creditor (BRI) and debtors (people who need loans). Next is the debtor and the creditor (BRI) conduct of a letter of credit agreement. In BRI Blora Preparation of letter of credit agreement made in front of a Notary.

- After making the letter of credit agreement is binding deed giro deposit guarantees.

\footnotetext{
${ }^{13}$ Sudarwan Denim, 2002, Menjadi Peneliti Kualitatif, Pustaka Setia, Bandung, p. 62

${ }^{14}$ Article 1150 and Article 1151 of the Civil Code

${ }^{15}$ Interview with Ms. Amelia, Credit Administration Staff, dated December 3, 2018

${ }^{16}$ Ibid.
} 
The second phase is in the form of loading objects pawn bail characterized by a deed granting of guarantees pledge, signed by the creditor and the debtor. The legislation does not specify a particular form of formality or deed lien certificates can be made so that the deed under hand or by an authentic deed. In this case the Kanca BRI Blora do a deed lien on an authentic deed before a Notary. In deed lien must be described on the object into the object. In all credit agreements in general use credit guarantees to creditors of the debtor submitted as collateral as well as in the credit agreement on BRI Blora, also using a credit guarantee deposit slip as collateral.

- The third stage is the most important stage in the collateral are objects that are used as collateral (deposit slip) should be withdrawn from power debtors and then secured objects at the mercy of creditors (BRI). The submission of a real delivery, which means that the deposit certificate must actually be submitted under the power of the banks, should not be only based on the declaration of the debtor alone. Real handover was conducted in conjunction with the juridical handover, so that the handover is an element of validity of the agreement.

- The fourth stage in conjunction with the third stage, depositors should authorize the bank to make disbursements of deposits in terms of depositors / borrowers in default. Authorization withdraw deposits are also tangible form submission judicial deposits to banks to facilitate the repayment of creditors in making loans secured by these deposits.

- The fifth stage is the creditor as the recipient pawn deposits will perform blocking or withdrawal of funds on deposit guarantees in accordance with the term of the credit agreement. This means that the loans as a principal agreement has not been paid then the whole of that collateral deposits blocked.

\subsection{Notary Role In Bonding Guarantee of Bilyet Deposits As Collateral Loan Process Loan Agreement (Case Study Kanca BRI Blora)}

Article 1 paragraph 7 of Banking Law deposits are deposits that can be withdrawn only at certain times based on an agreement with the bank Depositors. Time deposits according to the legislation included as one of the moving objects are intangible because it is considered a valuable letter ${ }^{17}$.

Time deposits represent a receivable on behalf seen from the proof of ownership of deposit slips so that if used as loan collateral by way of mortgaged ${ }^{18}$. While it was a deposit slip can not follow the workings of the certificate. This means that slip can not change hands as well as the sale, as it includes the name of the customer. If you want to melt it must be done by the customer who submitted deposits. Value of interest between the certificate and slips were different. The interest rate on the certificate required to be paid since the beginning of the filing, while the slip is paid when matured. The next difference is the deposit certificate can be extended even though the time period has expired. However, if the certificate would require a special procedure provided by the bank or financial institution to an investor ${ }^{19}$.

Overall, Notary a deed due to the request of the parties are facing, without any request from the parties, the notary will not make the deed any, and the notary a deed is based on evidence or information or statements/parties stated or explained or shown to or Notary, the Notary frame and then outwardly, formal and material in the form of notarial deed, to remain grounded in the rule of law and procedure or procedures deed and rules of law

\footnotetext{
${ }^{17}$ Article 511 of the Civil Code

${ }^{18}$ Article 1151 and Article 1152 of the Civil Code

${ }^{19}$ Interview with Mr. Rudi, staff Legal, December 3, 2018
} 
relating to the relevant legal action as outlined in the deed ${ }^{20}$.

The role of the PPAT Notary important because it will provide a written statement as to whether the collateral to be used is legitimate in the eyes of the law or not, but it PPAT Notary in the credit agreement should also be made a binding letter of agreement and deed of guarantee deposit slips. This deed as proof that it is their collateral between creditors and debtors that if at any time one of the parties in default can be used ${ }^{21}$.

Binding legal consequences if not done in front of a Notary Public is as follows ${ }^{22}$ :

- An agreement made under the deed in hand or loss of authenticity as stated in Article 16 paragraph (8) UUJN, resulting in the deed can not be registered.

- As the recipient if the imposition of collateral Mortgage done under the hands of the lender does not get a position that takes precedence (droit de preference).

- In the event of default, the guarantee can not be directly executed.

- Proof of the deed made does not apply to third parties.

- In case of dispute / dispute between two parties, the completion of which can be reached only through a settlement amicably, can not be passed into law.

- Financing affect member motivation to comply with good performance, it is usually greatly affects the smooth installment members in fulfilling their obligations.

\subsection{Obstacles and Solutions In Bonding Guarantee of Bilyet Deposits As Collateral Loan Process Loan Agreement (Case Study Kanca BRI Blora)}

For banks, attempts to provide security to every activity is important, for it to provide credit to borrowers in addition to a variety of technical and financial analysis was also done in terms of legal security, particularly through the binding of a strong guarantee. In practice, with the aim to streamline the process and expedite the realization of the credit, the binding is sometimes less collateral received considerable attention from the banking practitioners. The result is often the case that legally binding no or insignificant. This may occur because of the different ways in line with the binding guarantees various types of goods that can be guaranteed, which each have a base of different laws ${ }^{23}$. Acceptance of deposits as loan collateral by the bank would be a matter that is very advantageous, because of the availability of the value to be gained by banks when a loan has become problematic can be said to have been assured (certainty readmission of loans). Deposit as collateral is movable and deposits is one of the objects collateral pledge. Pawn is a guarantee of the right material, arising from mortgage agreement ${ }^{24}$. Deposit mortgage agreement has dimensions of contract law and legal dimensions of objects. Dimensions of treaty law lies in their deeds which are subject to agreement contract law which must meet the requirements specified in Article 1320 of the Civil Code.

Kanca BRI Blora in authors found no significant barriers in the binding process with the credit guarantees of Bilyets Deposit. Factors inhibiting factor Debtors (people who would do credit) in the form of lack of understanding about people who would credit, people are still unfamiliar with the terms of banking and credit application process with guarantee of a deposit slip. This causes the binding process becomes time consuming, as a solution to the Bank must give a detailed explanation before binding treaty process. While the party

\footnotetext{
${ }^{20}$ Habib Adjie, 2010, Hukum Notaris Indonesia-Tafsir Tematik Terhadap UU No. 30 Tahun 2004 tentang Jabatan Notaris, Rafika Adisama, Bandung, p. 24

${ }^{21}$ Interview with Mr. Aji, a notary in Blora, 21 November 2018

22 Ibid.

${ }^{23}$ Indrawati Soewarso, op. cit., h. 5

24 J. Satrio, 2004, Hukum Jaminan, Hak Jaminan, Kebendaan, Hak Tanggungan Buku 2, PT.Citra Aditya Bakti, Bandung, p. 32
} 
creditor was not found things that can hinder the process of obtaining loans with collateral deposit slips. In terms of billing to credit jammed, sometimes Parties creditor must send warning letters first, but until the third warning letter of creditor has paid off arrears, so temporary bilyet deposits that used as guarantee will not blocked or thawed by the Bank.

\section{Closing}

\subsection{Conclusion}

From the description above, it can be concluded as follows:

- Implementation binding guarantee term deposit certificate as collateral on the loan agreement in BRI Blora starting from the loan application stage, the stage of the agreement and the making of the loan agreement, the stage of a deed binding guarantee deposit slips, stage submission of collateral objects, stages of authorization and blocking or searching stage in case of default.

- In the process of BRI Blora Credit Agreement in Notary role in a written statement as to whether the collateral to be used is legitimate in the eyes of the law or not, but it PPAT Notary in the credit agreement should also be made a binding letter of agreement and deed of guarantee deposit slips. This deed as proof that it is their collateral between creditors and debtors that if at any time one of the parties in default can be used.

- Not found constraints or significant barriers, the barriers just a lack of understanding about the people who do the will of credit, people are still unfamiliar with the terms of banking and the credit application with a guarantee of a deposit slip, so that the Bank had to explain in detail before the binding agreement.

\subsection{Suggestion}

- To better meet the sense of justice in the implementation of the binding, the bank in this case the creditor provides sufficient grace period to the debtor if the debtor in default and not too short grace period to pay. Because the bank already exists in the safe position for holding the deposit slip of the debtor.

- To speed up the process of credit agreement, The Bank BRI Blora to be more intensely socialized to the community banking.

\section{Bibliography}

[1] Act No. 2 of 2014 concerning on Notary

[2] Amiruddin, 2012, Pengantar Metode Penelitian Hukum, Rajagrafindo Persada, Jakarta

[3] Habib Adjie, 2008, Sanksi Perdata dan Administratif Terhadap Notaris Sebagai Pejabat Publik, Refika Aditama, Bandung

[4] Habib Adjie, 2010, Hukum Notaris Indonesia-Tafsir Tematik Terhadap UU No. 30 Tahun 2004 tentang Jabatan Notaris, Rafika Adisama, Bandung

[5] Indrawati Soewarso, 2002, Aspek Hukum Jaminan Kredit, Institut Bankir Indonesia, Jakarta

[6] J. Satrio, 2004, Hukum Jaminan, Hak Jaminan, Kebendaan, Hak Tanggungan Buku 2, PT.Citra Aditya Bakti, Bandung

[7] Kohar, 1983, Notaris Dalam Praktek Hukum, Alumni, Bandung

[8] Mukti Fajar dan Yulianto, 2010, Dualisme Penelitian Hukum Normatif dan Empiris, Pustaka Pelajar, Yogyakarta

[9] Ronny Hanitijo soemitro, 1982, Metodologi Penelitian Hukum, Ghalila Indonesia,. Jakarta

[10] Sudarwan Denim, 2002, Menjadi Peneliti Kualitatif, Pustaka Setia, Bandung Sumardi Suryabrata, 1993, Metodologi Penelitian, Rajawali, Jakarta 